\title{
408 パーライトパテント材の引張変形中その場中性子回折
}

In situ neutron diffraction under tensile deformation for patented pearlite steels

\author{
○学 篠崎 智也（茨城大）学 諸岡 聡（茨城大・院） \\ 鈴木，徹也（茨城大）正 友田 陽（茨城大・院）
}

Tomoya Shinozaki, Faculty of Engineering student, Ibakaki University, 4-12-1 Nakanarusawa, Hitachi, Ibaraki, 316-8511

Satoshi Morooka, Graduate student of Ibaraki University, 4-12-1 Nakanarusawa, Hitachi, Ibaraki, 316-8511

Testuya Suzuki, Faculty of Engineering, Ibakaki University, 4-12-1 Nakanarusawa, Hitachi, Ibaraki, 316-8511

Yo Tomota, Graduate school of Ibaraki University, 4-12-1 Nakanarusawa, Hitachi, Ibaraki, 316-8511

When plastic deformation is given to pearlite steel, misfit strain generates between cementite and ferrite. Even in the ferrite matrix, stress is different from grain to grain depending on the crystal orientation. This "block stress" stems from the heterogeneous plastic flow among differently oriented blocks and must be influenced by texture. In this study, therefore, in situ neutron diffraction under tensile deformation for as-patented pearlite steels with weak texture were conducted in order to estimate the strength anisotropy in the crystal orientation of ferrite blocks. Consequently, it was found that (110) and (211) ferrite family blocks in the pearlite steels are harder than (200) ferrite family ones.

Key Words: Pearlite Steel , Microstructure , Neutron Diffraction, Plastic Deformation

\section{1. 緒言}

パーライト組織を有する鉄鋼材料は、伸線加工することで ピアノ線のように高強度を示すことで知られる。パーライト は Fig.1 に示すような組織であり、旧オーステナイト粒が 1 つのブロックを形成し、その内にフェライトとセメンタイト からなるいくつかのコロニーが形成されている。この組織を 有するパーライト鋼を伸線加工した場合、次の 4 つの原因で 残留応力が形成される。（1）フェライトとセメンタイトの 強度差に起因する相応力、（2）フェライトの結晶方位異方 性によるブロック応力、（3）ラメラ方位による強度差に起 因するラメラ応力、(4) 伸線加工による内部と外部の塑性 流動の差に起因寸るマク口応力。それらの残留応力を原因別 に分離することは一般に難しいが、透過力の高い中性子回折 を用いれば、試料全体の情報を含むことから（3）、（4）の 応力は無視できると考えられる。

我々の研究グループではこの中性子回折を利用して、伸線 パーライト鋼の内部応力について検討してきた ${ }^{1)}$ 。の結果、 相応力についてはある程度の知見が得られたが、伸線加工す ると、集合組織の影響をうける（2）のブロック応力につい ては、いまだ明らかでない点がある。そこで、本研究では、 集合組織をもたないパーライトパテント材の引張変形中の その場中性子回折を行い、ブロック応力発生の原因となる結 晶方位の強度異方性について検討した。

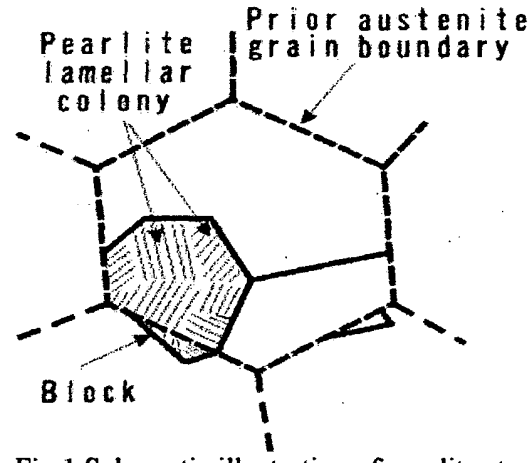

Fig. 1 Schematic illustration of pearlite structure

\section{2. 実験方法}

本研究で使用した試料は、大同特殊鋼（株）において作製

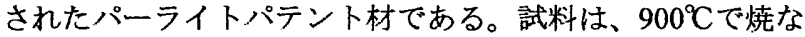
らし後、恒温処理 $\left(400^{\circ} \mathrm{C}\right)$ した Fe-0.8C (0A)、Fe-2.5Ni-0.8C
(2A) および Fe-5.0Ni-0:8C (5A)、恒温処理 $\left(550^{\circ} \mathrm{C}\right)$ の $\mathrm{Fe}-0.8 \mathrm{C}$ (0C)、 Fe-2.5Ni-0.8C（2C）および Fe-5.0Ni-0.8C（5C）老用 いそれらの化学組成を Table1 に示す。引張変形中その場中 性子回折実験は、高工ネルギー加速器研究機構中性子散乱研 究施設に設置されている高分解能中性子回折装置 SIRIUS を 用いて、飛行時間法 (TOF 法) により各パテント材の降伏点 付近の応力下で測定した。その回折プロファイル例および SIRIUS の引張方向、入射・回折ビーム、バンクの関係を Fig.2 に示す。

Table 1 Chemical compositions of pearlitic steel(mass\%)

\begin{tabular}{|l|l|l|l|l|l|l|}
\hline 成分元素 & $\mathrm{C}$ & $\mathrm{Si}$ & $\mathrm{P}$ & $\mathrm{S}$ & $\mathrm{Cu}$ & $\mathrm{Ni}$ \\
\hline $\mathrm{Fe}-0.8 \mathrm{C}$ & 0.801 & $<0.01$ & $<0.01$ & $<0.01$ & $<0.01$ & $<.01$ \\
\hline $\begin{array}{l}\mathrm{Fe}-2.5 \mathrm{Ni}- \\
0.8 \mathrm{C}\end{array}$ & 0.815 & 0.01 & 0.002 & 0.001 & $<0.01$ & 2.5 \\
\hline $\begin{array}{l}\mathrm{Fe}-5.0 \mathrm{Ni}- \\
0.8 \mathrm{C}\end{array}$ & 0.800 & 0.01 & 0.001 & 0.001 & $<0.01$ & 5.0 \\
\hline
\end{tabular}

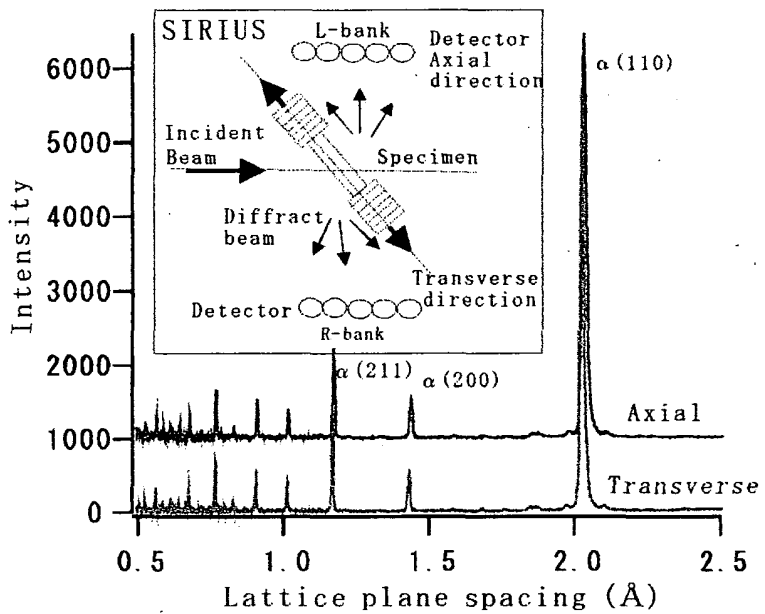

Fig.2 Diffraction profiles obtained by TOF method and Layout for lattice strain measurement during tensile deformation.

\section{3. 結果及び考察}

パーライトパテント材の引張変形中その場中性子回折に より得られた回折プロファイルは、回折強度は $\alpha(110)$ は高く、 それ以外は極端に低い。ピークシフトを追える $\alpha(110) 、 \alpha$ (200)、 $\alpha(211)$ をイッティングし、ピーク位置を決定し、 
格子面ひずみを計算した。TOF 法は入射ビームスペクトルが 非対称なので、Gauss 関数、Lorentz 関数および指数関数でフ イッティングし、フィッティング精度としては十分高い $0.001 \sim 0.01 \%$ の誤差範囲で計算できた。 $0 \mathrm{~A}$ 鋼、2A 龬および 5A 鋼における格子面ひずみの引張応力における変化を Fig.3

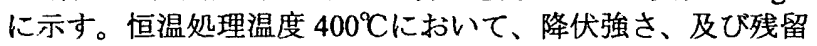
ひずみは Ni 添加に伴い大きくなっていることがわかる。ま た、恒温処理温度の異なる $2 \mathrm{~A}$ 鋼および $2 \mathrm{C}$ 鋼の $\alpha(110)$ 格子 面ひずみの引張応力におうるる変化を Fig.4 に示す。恒温処理 温度が低いほど、降伏強さが大きいことがわかる。パーライ 卜鋼は、恒温処理温度が低いほどラメラ間隔 $\left(\mathrm{S}_{0}\right)$ が小さい2)。 従って、降伏強さはラメラ閒隔 $\left(\mathrm{S}_{0}\right)$ に支配されると推測され る。

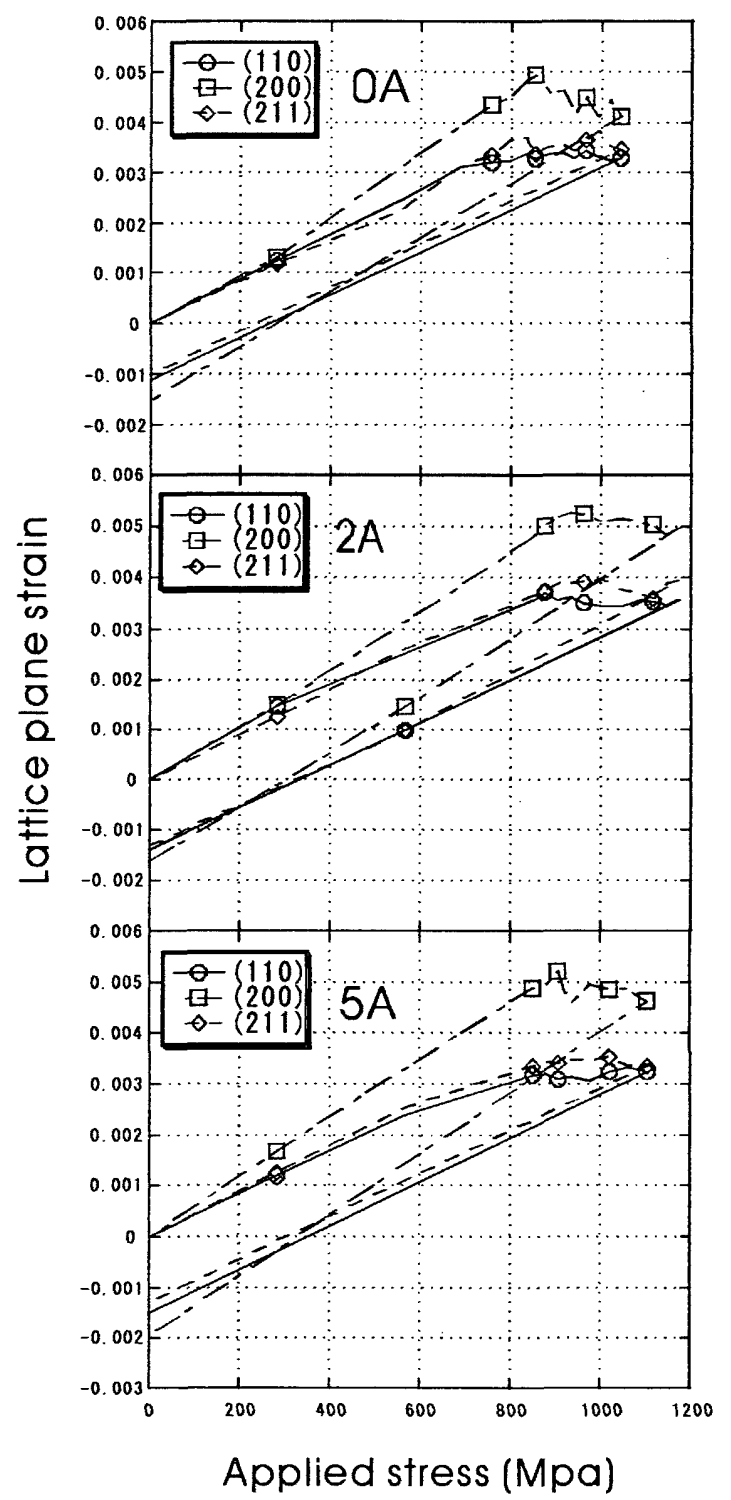

Fig.3 Lattice plane strain as a function of the applied stress for $0 \mathrm{~A}, 2 \mathrm{~A}$ and $5 \mathrm{~A}$ steels. (isothermally transformed at $673 \mathrm{~K}$ )

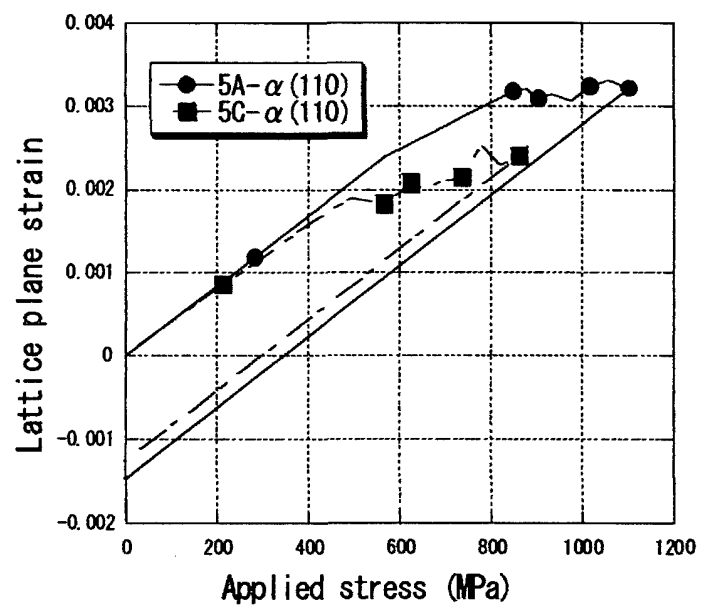

Fig.4 $\alpha(110)$ Lattice plane strain as a function of the applied stress for $5 \mathrm{~A}$, and $5 \mathrm{C}$ steels.(isothermally transformed at $400^{\circ} \mathrm{C}(5 \mathrm{~A})$ and $\left.550^{\circ} \mathrm{C}(5 \mathrm{C})\right)$

また、Fig.3 から、(110)と(211)はほほ同じ傾向が見られる ことが確認される。しかし、(200)はこれらとは異なり、弹性 係数に大きく影響を及ぼした。0A 鋼の(110)、(200)执よび (211)の弾性係数は228GPa、177GPa、226GPa である。Table2 に 0A、2A、5A 鋼における(110)、(200)および(211)の弾性係 数の值を示す。Ni を添加した炭素鋼 2A、5Aについてもこれ らの面における弹性係数の傾向は同様にみられ、Ni 添加した $2 \mathrm{~A}$ 銅および $5 \mathrm{~A}$ 銅では、 $\alpha(110)$ 弾性係数が比較的大きくな ることがわかった。

Table2 (110)、(200)、(211) diffraction Young's modulus (GPa)

\begin{tabular}{c|c|c|c|c}
\multicolumn{2}{c|}{ steel } & $(110)$ & $(200)$ & $(211)$ \\
\hline Fe-0.8C & 0A & 228 & 177 & 226 \\
\hline Fe-2.5Ni-0.8C & $2 \mathrm{~A}$ & 241 & 184 & 235 \\
\hline Fe-5.0Ni-0.8C & $5 \mathrm{~A}$ & 262 & 172 & 238 \\
\hline
\end{tabular}

4.結言

引張変形におけるフェライトの(110)、(200)および(211)回 折格子面ひずみを、中性子回折により測定した。その結果か ら、フェライトの結晶方位度異方性が確認され、(200)のブロ ック店力は(110)执よび(211)よりも低く、弾性係数に执いても、 (200)は(110)、(211)よりも低い值を示した。また、Niを添加 することにより、降伏強さの増加が見られ、(110)回折弾性係 数が大きくなることがわかった。

\section{参考文献}

1) Y.Tomota, A.Kanie, and T.Suzuki : Materials Science,Vols. 426-432(2003) pp.1571-1576

2) Y.Tomota, O.Watanabe, A.Kanie, A.Moriai, N.Minakawa and Y.morii : Materials.Science and Technology., 19(2003)pp.1715 